Original Article

\title{
Pengaruh Cahaya LED Putih di Malam Hari Terhadap Kadar Malondialdehyde (MDA) Otak dan Histopatologi Sel CA3 dan CA1 Hipokampus Pada Tikus Wistar Jantan Jantan
}

\author{
Effect of White LED Light at Night on Brain Malondialdehyde (MDA) Levels and \\ Histopathology of Hippocampal CA3 and CA1 Cells in Male Wistar Rats
}

\section{Hilda Emma Mallisa ${ }^{1 *}$, Aryadi Arsyad ${ }^{2}$, Irfan Idris ${ }^{2}$}

${ }^{1}$ Magister Biomedik, Pascasarjana Universitas Hasanuddin, Makassar, Indonesia

${ }^{2}$ Departemen Fisiologi, Fakultas Kedokteran, Universitas Hasanuddin, Makassar, Indonesia

(*hildamallisa07@gmail.com, 082322289893)

\begin{abstract}
ABSTRAK
Penelitian ini bertujuan untuk mengalisis pengaruh cahaya LED putih di malam hari terhadap kadar malondialdehyde (MDA) otak dan histopatalogi sel CA3 dan CA1 hipokampus. Jenis penelitian true eksperimental dengan post-test only control group design yang dilakukan pada 24 ekor tikus. Kelompok terbagi berdasarkan waktu paparannya: 15 hari dan 30 hari, masing-masing memiliki kelompok kontrol dan perlakuan. Kelompok kontrol: terang-gelap normal (12L:12D) dan kelompok perlakuan: terang-terang (12L:12L) dengan pencahayaan berasal dari lampu LED putih 1500 lux saat malam hari. Hasil penelitian menunjukkan kadar MDA otak pada kelompok perlakuan lebih tinggi dibandingkan dengan kelompok kontrol dan signifikan ( $\mathrm{p}=0,001)$. Hasil pemeriksaan histopatologi sel CA3 dan CA1 pada kelompok perlakuan 15 hari didapatkan mengalami kerusakan sedang $(50 \%)$ hingga berat $(50 \%)$ sedangkan pada kelompok kontrol 15 hari hanya dominan pada kerusakan ringan $(83,3 \%)$ dengan hasil yang signifikan $(\mathrm{p}=0,011)$. Pada kelompok perlakuan 30 hari dominan mengalami kerusakan berat $(83,3 \%)$ sedangkan pada kelompok kontrol 30 hari berada diantara kerusakan ringan $(33,3 \%)$ hingga sedang $(66,7 \%)$ dan hasil yang diperoleh signifikan $(\mathrm{p}=0,012)$. Cahaya LED putih di malam hari bertindak sebagai stressor apabila intensitas, durasi paparan dan panjang gelombangnya sesuai. Stressor ini meningkatkan produksi ROS dan mengarahkan sel pada stress oksidatif yang ditandai dengan meningkatnya kadar MDA. Peningkatan kadar MDA bersifat neurotoksik pada otak khususnya hipokampus yang mengarahkan sel CA3 dan CA1 pada kerusakan maka perlu adanya pengurangan dalam penggunaan lampu LED pada malam hari.
\end{abstract}

Kata kunci : Cahaya, LED, MDA, Hipokampus, Ritme Sirkadian.,

\section{ABSTRACT}

This study aims to determine the effect of white LED light at night on brain malondialdehyde (MDA) levels and histopathology of hippocampal CA3 and CA1 cells A true experimental research with a post-test only control group design on 24 rats. The group is divided according to the time of its expose: 15 days and 30 days, each with a control group and treatment. The control group: light-dark cycle $(12 \mathrm{~L}: 12 \mathrm{D})$ and the treatment group: light-light cycle (12L: 12L) with the lighting coming from the white 1500 lux LED light at night The results showed that brain MDA levels in the treatment group were higher than the control group and significant $(p=0,001)$. The results of histopathological examination of hippocampal CA3 and CA1 cells in the 15-days treatment group were found to have moderate (50\%) to severe (50\%) damage, whereas in the 15-days control group only dominant in mild damage $(83,3 \%)$ with significant results $(p=0,011)$. The 30-days treatment group dominant suffered heavy damage (83,3\%), whereas in the 30-days control group were between mild (33,3\%) to moderate $(66,7 \%)$ damage and the results obtained were significant $(p=0,012)$. White LED light at night acts as a stressor when the intensity, duration of exposure and wavelength are appropriate. This stressor increases the production of ROS and directs cells to oxidative stress which is characterized by increased levels of MDA. Increased levels of MDA are neurotoxic for brain, especially the hippocampus which then directs CA3 and CA1 cells to damage, Increased free radicals will direct CA3 and CA1 cells to damage, so it is necessary to reduce the use of LED lights at night.

Keywords : Light, LED, MDA, Hippocampus, Circadian Rhythm

https://doi.org/10.33860/jik.v15i2.452 


\section{PENDAHULUAN}

Meluasnya penggunaan cahaya buatan di malam hari menjadi salah satu faktor penyebab meningkatnya berbagai gangguan kesehatan dalam masyarakat modern ${ }^{1}$. LED putih saat ini merupakan jenis pencahayaan buatan yang banyak digunakan hampir diseluruh dunia. Teknologi yang tahan lama, hemat energi, murah membuat lampu jenis ini semakin banyak digunakan ${ }^{2}$.

Dikenal akan keunggulannya namun lampu LED putih memiliki masalah terkait spektrum biru pada komponennya ${ }^{3}$. Cahaya biru yang dihasilkan oleh lampu LED secara khusus akan mengganggu ritme sirkadian, mempengaruhi metabolisme, sekresi hormon, ekspresi gen dan aktivitas enzim, terlebih jika paparannya terjadi di malam hari meski cahayanya tidak terlalu terang ${ }^{4},{ }_{1}$. Selain itu juga akan berdampak pada kinerja dan kesehatan mental pada manusia ${ }^{5}$. Dalam situasi ini, seseorang terpapar cahaya buatan di malam hari bergantung dari pilihan gaya hidup, misalnya penggunaan gadget, lokasi tempat tinggal (terutama daerah perkotaan), pekerjaan shift malam dan kebiasaan begadang.

Paparan cahaya di malam hari dianggap sebagai stressor lingkungan. Tingkat kecerahan cahaya yang tinggi menjadi pemicu stress bagi manusia ${ }^{1}$. Cahaya LED putih di malam hari merupakan stressor yang dapat memicu radikal bebas dan mengarahkan sel pada stress oksidatif 6. Radikal bebas yang terlalu banyak akan merusak komponen pada salah satu membran sel, yakni lipid yang kemudian disebut peroksidasi lipid ${ }^{7}$. Salah satu produk akhir dari peroksidasi lipid yaitu malondialdehyde (MDA). Konsentrasi MDA yang tinggi mengarahkan sel pada kerusakan ${ }^{8}$.

Peningkatan peroksidasi lipid dan akumulasi penuruan-penurunan metabolit bersifat neurotoksik. Stress oksidatif dapat mengganggu aktivitas enzim $\mathrm{Ca} 2+$ ATPase yang berperan dalam proses regulasi konsentrasi $\mathrm{Ca} 2+$ intraseluler. Otak yang tidak kaya akan enzim atau senyawa antioksidan yang berperan sebagai bahan protektif akan membuat radikal bebas diproduksi dan menyebabkan kematian pada sel. Selain itu, tingginya hormon glukokortikoid yang disekresikan saat stress juga menjadi penyebab kematian pada sel neuron di hipokampus terutama bagian cornu ammonis yakni sel CA3 dan CA1 sangat rentan terhadap stress karena perannya dalam regulasi neuroendokrin dari hormon stress. Berbagai gangguan ini menyebabkan perubahan pada konsentrasi protein dan asam amino, penurunan kadar antioksidan, perubahan morfologi dan struktur mitokondria yang pada akhirnya menyebabkan nekrosis pada sel $^{9}$.

Beberapa penelitian terkait pengaruh cahaya di malam hari telah dilakukan dimana obesitas dan gangguan metabolisme menjadi efek negatif cahaya buatan di malam hari yang paling sering ditemukan. Namun, penelitian yang meneliti pengaruh dari cahaya LED putih di malam hari terhadap kadar MDA di otak serta terjadinya kerusakan sel pada daerah CA3 dan CA1 masih sangat jarang dilakukan. Alasan ini menarik bagi peneliti mengingat saat ini pilihan gaya hidup membuat seseorang selalu terpapar cahaya.

Penelitian ini bertujuan untuk mengetahui pengaruh cahaya LED putih di malam hari terhadap kadar malondialdehyde (MDA) otak dan histopatalogi sel CA3 dan CA1 hipokampus.

\section{METODE PENELITIAN}

Jenis penelitian true eksperimental dengan Posttest-Only Control Group Design yang dilaksanakan di Laboratorium Fakultas Farmasi Universitas Hasanuddin dan Laboratorium Terpadu Klinik Hewan Pendidikan Universitas Hasanuddin Makassar. Sampel dalam penelitian ini adalah tikus wistar jantan sebanyak 24 ekor yang telah memenuhi kriteria inklusi dan eksklusi. Kriteria inklusi: tikus berusia 12-16 minggu, memiliki berat \pm 200 gr, bergerak aktif, sehat dan tidak cacat secara fisik. Kriteria eksklusi: tikus yang tampak sakit dan tikus yang mati saat proses aklimatisasi. Tikus dalam penelitian ini akan dipaparkan cahaya LED putih dengan intensitas 1500 lux pada malam hari, mulai pukul 6 sore - pukul 6 pagi (12 jam) selama 15 hari dan 30 hari, setelah itu dilakukan pemeriksaan kadar MDA pada otak dan histopatologi sel CA3 dan CA1 hipokampus. Cahaya LED putih 1500 lux sebagai variabel bebas, sedangkan kadar MDA otak dan histopatologi sel CA3 dan CA1 sebagai variabel terikat. Penelitian ini telah mendapat izin dari Komite Etik Penelitian Hewan di Fakultas Kedokteran Universitas Hasanuddin Makassar pada tanggal 15 Februari 2021 dengan nomor Protokol UH21020081.

Seluruh sampel diaklimatisasi selama 3 minggu dengan siklus pencahayaan terang- 
gelap (12L:12D). Sampel terbagi dalam 2 kelompok yaitu kelompok 15 hari dan kelompok 30 hari, setiap kelompok terdiri dari kelompok kontrol dan perlakuan sehingga total menjadi 4 kelompok yang masing-masing terdiri dari 6 ekor tikus. Setiap kelompok ditempatkan dalam kandang yang terbuat dari bahan plastik berukuran $51 \times 31 \times 21 \mathrm{~cm}$ kemudian ditempatkan lagi dalam kandang khusus yang terbuat dari balok dan tripleks berukuran $105 \times 60 \times 65 \mathrm{~cm}$. Khusus untuk kandang kelompok perlakuan dipasangi lampu LED putih dengan pencahayaan 1500 lux yang dirakit secara paralel. Lampu LED yang digunakan adalah jenis lampu LED putih (cool white) 18-watt dengan suhu cahaya $7000 \mathrm{~K}$ sebanyak 2 buah. Pencahayaan 1500 lux pada ruangan kandang kelompok perlakuan

Kelompok kontrol dipelihara dalam siklus pencahayaan terang-gelap normal (12L:12D) selama 15 hari dan 30 hari. Ketika siang hari, kelompok kontrol mendapat cahaya matahari selama 12 jam (pukul 6 pagi - 6 sore) dan ketika malam hari tikus dipelihara dalam gelap selama 12 jam (pukul 6 sore -6 pagi). Sementara untuk kelompok perlakuan dipelihara dalam siklus pencahayaan terang-terang (12L:12L) selama 15 hari dan 30 hari. Ketika siang hari, kelompok perlakuan mendapat cahaya alami (sinar matahari) selama 12 jam (pukul 6 pagi - 6 sore) dan ketika malam hari malam hari tikus akan dipaparkan cahaya lampu LED putih dengan intensitas 1500 lux selama 12 jam (pukul 6 sore - 6 pagi). Pada malam hari kedua kandang ini akan ditutup oleh kain hitam untuk menghindari paparan cahaya lain dari lingkungan sekitar. Selama proses penelitian, setiap kelompok diberi pakan standar (AD2) dan air minum secara ad libitum.

Pada hari ke-16 dan hari ke-31 tikus diterminasi dengan melakukan dislokasi leher, dilanjutkan dengan pembedahan kepala dan pengambilan otak. Otak dipotong secara coronal untuk dibuat preparat histologisnya sedangkan bagian otak lainnya yang tidak digunakan untuk pemeriksaan histologi, digunakan untuk pengukuran kadar MDA. Pengukuran kadar MDA dilakukan secara spektrofotometrik sedangkan pemeriksaan histologi dilakukan dengan pewarnaan Hematoksilin-Eosin (HE) dengan parameter kerusakan sel CA3 dan CA1 hipokampus yaitu perubahan morfologi sel berupa degenerasi dan nekrosis yang diklasifikasikan ke dalam tiga kategori penilaian berdasarkan persentase dari kerusakan sel yang terlihat dari seluruh pandang, yaitu: kerusakan ringan (bila persentase kerusakan sel 25\%), sedang (bila persentase kerusakan sel 50\%) dan berat (bila persentase kerusakan sel $\geq 75 \%$ ) yang diperiksa dibawah mikroskop Olympus dengan pembesaran 400x.

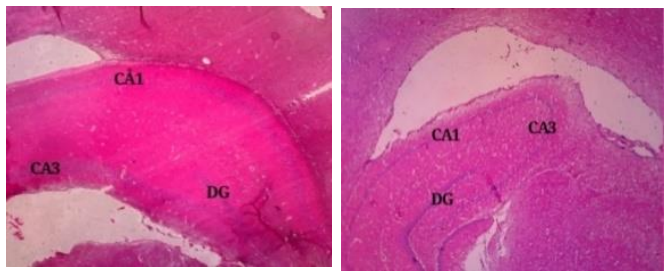

Gambar 1. Hasil Gambaran Mikroskopis Sampel

Penelitian. Potongan Coronal melalui Sumbu

Transversal pada Hipokampus (CA1, CA3 dan DG)

Data selanjutnya dianalisis menggunakan

Program SPSS 16.0. Data numerik diuji normalitasnya menggunakan uji Saphiro-Wilk karena jumlah sampel $<50$. Uji Independent $t$ test digunakan karena data berdistribusi normal. $\mathrm{Uji}$ Independent t-test digunakan untuk membandingkan kadar MDA otak antara kelompok kontrol dan perlakuan. Uji nonparametrik Chi-Square digunakan untuk membandingkan tingkat kerusakan sel CA3 dan CA1 hipokampus antara kelompok kontrol dan perlakuan

\section{HASIL}

Setelah menganalisis data karakteristik sampel, maka dilanjutkan dengan menganalisis perbedaan kadar MDA otak antara kelompok kontrol dan kelompok perlakuan. Berdasarkan hasil penelitian, terlihat bahwa kadar MDA lebih tinggi ditemukan pada kelompok 30 hari yaitu pada kelompok perlakuan $(0,49 \pm 0,01$ $\mathrm{nmol} / \mathrm{ml})$. Hasil rerata kadar MDA otak dari setiap kelompok dapat dilihat pada Gambar 2.

Setelah mengetahui hasil pengukuran kadar MDA dari setiap kelompok, selanjutnya dilakukan uji Independent t-test untuk membandingkan kadar MDA antara kelompok kontrol dan kelompok perlakuan berdasarkan waktu paparannya. Hasil uji menunjukkan bahwa kadar MDA pada kelompok perlakuan 15 hari lebih tinggi yaitu $0,33 \pm 0,05 \mathrm{nmol} / \mathrm{ml}$ homogenate dibandingkan dengan kadar MDA pada kelompok kontrol 15 hari yaitu $0,15 \pm 0,04$ $\mathrm{nmol} / \mathrm{ml}$ homogenate $(\mathrm{p}=0,001)$. Kadar MDA pada kelompok perlakuan 30 hari lebih tinggi yaitu $\quad 0,49 \pm 0,01 \quad \mathrm{nmol} / \mathrm{ml}$ homogenate dibandingkan dengan kadar MDA pada 
kelompok kontrol 30 hari yaitu $0,21 \pm 0,02$ $\mathrm{nmol} / \mathrm{ml}$ homogenate $(\mathrm{p}=0,001)$ (Tabel 2).

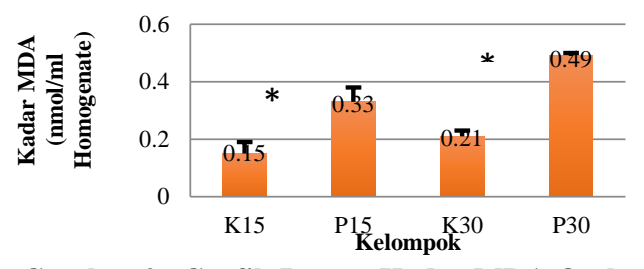

Gambar 2. Grafik Rerata Kadar MDA Otak pada

Ket:

Tiap Kelompok

K15 = Kontrol 15 Hari

P15 = Perlakuan 15 Hari

$\mathrm{K} 30=$ Kontrol 30 Hari

P30 = Perlakuan 30 Hari

* =Meningkat secara signifikan dibanding kelompok kontrol masing-masing

Tabel 2. Kadar MDA Otak pada Kelompok Kontrol dan Perlakuan yang Dipapar Cahaya LED selama 15 hari dan 30 hari Kadar MDA

\begin{tabular}{ccc}
\hline Kelompok & $\begin{array}{c}\text { Kadar MDA } \\
\text { (nmol/ml homogenate) } \\
\text { Mean } \pm \text { SD }\end{array}$ & $\mathrm{p}$ \\
\hline K15 & $0,15 \pm 0,04$ & \\
P15 & $0,33 \pm 0,05$ & $\mathbf{0 , 0 0 1 *}$ \\
\hline K30 & $0,21 \pm 0,02$ & \\
P30 & $0,49 \pm 0,01$ & $\mathbf{0 , 0 0 1}^{*}$ \\
\hline
\end{tabular}

Ket : Data diuji menggunakan uji Independent t-test. *signifikan $\mathrm{p}<0,05$

Tabel 3. Kerusakan Sel CA3 dan CA1 pada

Kelompok Kontrol dan Perlakuan yang Dipapar Cahaya LED Selama 15 Hari dan 30 Hari

\begin{tabular}{ccccc}
\hline & \multicolumn{3}{c}{ Kerusakan } & \\
\cline { 2 - 4 } Kel & Ringan & Sedang & Berat & p \\
\hline K15 & $5(83,3 \%)$ & $1(16,7 \%)$ & - & $\mathbf{0 , 0 1 1 *}$ \\
P15 & - & $3(50 \%)$ & $3(50 \%)$ & \\
K30 & $2(33,3 \%)$ & $4(66,7 \%)$ & - & $\mathbf{0 , 0 1 2 *}$ \\
P30 & - & $1(16,7 \%)$ & $5(83,3 \%)$ & \\
\hline
\end{tabular}

Ket : Data diuji menggunakan uji Chi Square. *signifikan jika $\mathrm{p}<0,05$

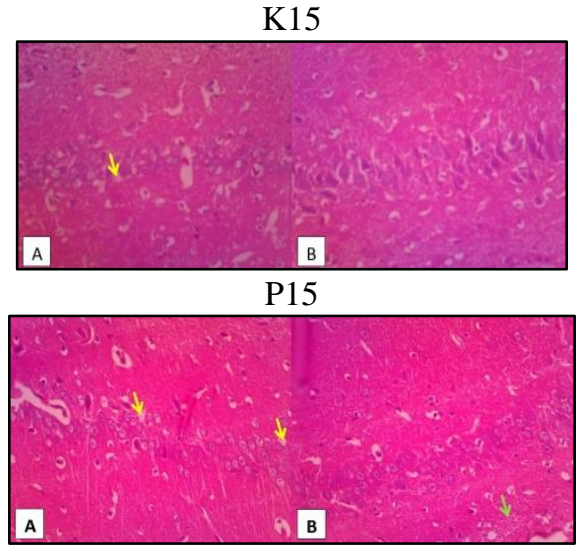

Gambar 2. Gambaran Mikroskopis Hipokampus Kelompok Kontrol 15 Hari (K15) dan Perlakuan 15 Hari (P15). Sel CA1 (A) dan Sel CA3 (B). Vakuolisasi (Panah Kuning) dan Nekrosa Sel (Panah Hijau). Pembesaran 400x (HE).
Hasil pengamatan gambaran mikroskopis sel CA3 dan CA1 hipokampus menunjukkan pada kelompok K15 terlihat banyak sel normal dimana sel berbentuk poligonal, sitoplasma utuh berwarna merah keunguan serta terlihat dinding sel berbatas tegas tetapi dalam pengamatan juga didapatkan satu sel yang mengalami kerusakan yaitu degenerasi hidropik yang ditandai dengan adanya vakuola-vakuola yang jernih, sitoplasma yang pucat dan sembab karena akumulasi air dalam sitoplasma. Sementara pada kelompok P15 terlihat dua sel yang mengalami kerusakan yaitu degenerasi hidropik yang ditandai dengan vakuolisasi sitoplasma dimana sitoplasma terlihat pucat dan sembab. Dibagian lain ternyata nampak satu sel yang mengalami nekrosis yang ditandai dengan nukleus yang berbentuk piknosis, nukleus terlihat kabur/tidak jelas dan karena membran sel mengalami lisis sehingga batas antar sel nampak tidak jelas (Gambar 2).

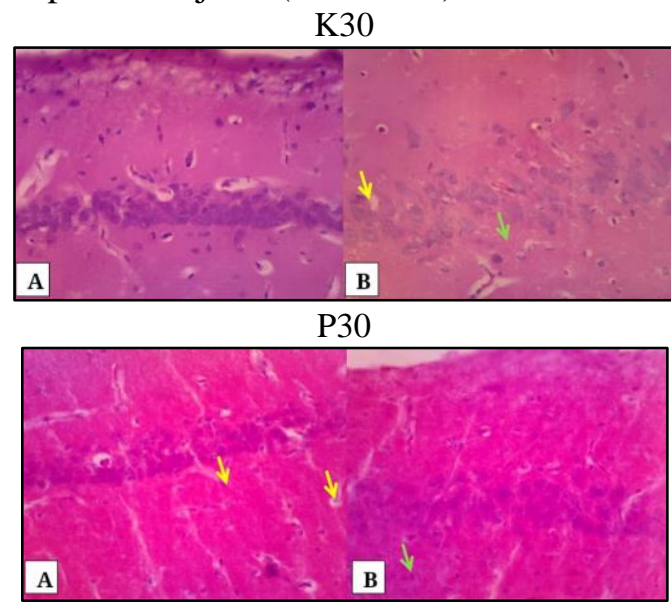

Gambar 3. Gambaran Mikroskopis Hipokampus Kelompok Kontrol 30 Hari (K30) dan Perlakuan 30 Hari (P30). Sel CA1 (A) dan Sel CA3 (B). Vakuolisasi (Panah

Kuning) dan Nekrosa Sel (Panah Hijau). Pembesaran 400x (HE)

Hasil pengamatan gambaran mikroskopis sel CA3 dan CA1 hipokampus menunjukkan pada kelompok K30 terlihat satu sel yang mengalami kerusakan yaitu degenerasi hidropik dimana sel nampak sembab, sitoplasma yang pucat dan mengalami vakuolisasi. Dari pengamatan ternyata terdapat juga satu sel yang mengalami nekrosis yang ditandai nukleus piknotik, lisis dan batas antar sel tidak jelas. Sementara pada kelompok P30 terlihat dua sel yang mengalami degenerasi hidropik dimana nampak sitoplasma yang mengalami vakuolisasi dan dibagian lain ternyata juga nampak satu sel yang mengalami nekrosis dimana nampak nukleus mengkerut dan 
mengecil juga batas antar sel nampak tidak jelas (Gambar 3).

Hasil uji Chi-Square menunjukkan kelompok P15 berada diantara kerusakan sedang (50\%) hingga berat $(50 \%)$ dimana ditemukan 3 yang mengalami kerusakan sedang dan 3 yang mengalami kerusakan ringan, sedangkan pada kelompok K15 dominan berada dalam kategori kerusakan ringan $(83,3 \%)$ dimana terdapat 5 yang mengalami kerusakan ringan dan hanya 1 yang mengalami kerusakan sedang yang secara statistik diperoleh hasil yang signifikan $(\mathrm{p}=0,011)$. Sementara pada kelompok P30 dominan berada dalam kategori kerusakan berat $(83,3 \%)$ dimana ditemukan 1 yang mengalami kerusakan sedang dan 5 yang mengalami kerusakan berat, sedangkan kelompok K30 berada diantara kerusakan ringan $(33,3 \%)$ hingga sedang $(66,7 \%)$ dimana ditemukan 2 yang mengalami kerusakan ringan dan 4 yang mengalami kerusakan sedang dan hasil yang diperoleh signifikan $(\mathrm{p}=0,012)$.

\section{PEMBAHASAN}

Sebagian besar polutan lingkungan menyebabkan efek kesehatan yang negatif ketika manusia terpapar jumlah yang melebihi ambang batas. Dalam kasus cahaya, "jumlah" yang dimaksud tidak hanya intensitas tetapi juga durasi dan siklus paparan. Ini artinya paparan cahaya buatan di malam hari yang menyebabkan efek kesehatan yang buruk bukan hanya diartikan sebagai cahaya yang berlebihan dalam hal kecerahan tetapi juga diartikan sebagai cahaya yang tidak diinginkan di malam hari ${ }^{1}$. Salah satu jenis cahaya buatan manusia yang kita ketahui yakni cahaya LED. Cahaya ini merupakan jenis cahaya buatan yang mengandung cahaya biru pada komponennya. Diketahui cahaya biru memiliki efek lebih signifikan terhadap ritme biologis dan melatonin yang kemudian dapat mempengaruhi homeostasis tubuh.

Menurut hasil penelitian ini, MDA meningkat secara signifikan pada jaringan yang diperiksa dimana antara kelompok kontrol dan kelompok perlakuan terdapat perbedaan yang signifikan. Hasil ini sesuai dengan penelitian sebelumnya terkait cahaya di malam hari yang dilakukan oleh Nathiya dan Vanisree (2010) yang menunjukkan bahwa hanya dalam 7 hari terjadi peningkatan TBARS pada tikus yang diinduksi cahaya di malam hari ${ }^{10}$. Pada penelitian ini kadar MDA otak pada kelompok yang dipapar cahaya lampu LED putih intensitas 1500 lux dengan cahaya lebih dingin (7000K) di malam hari selama 15 hari dan 30 hari hasilnya jauh lebih tinggi dibanding kelompok yang ditempatkan dalam siklus terang-gelap normal. Hasil ini membuktikan bahwa paparan cahaya lampu LED putih di malam hari dengan durasi dan intensitas tertentu dapat menyebabkan stress oksidatif yang ditandai dengan peningkatan kadar peroksidasi lipid yaitu MDA. Hasil ini sama seperti yang diungkapkan Bascha et al (2016) dalam penelitiannya yang membuktikan bahwa terjadi peningkatan peroksidasi lipid otak pada tikus wistar setelah dipapar cahaya pada malam hari selama 15 dan 30 hari ${ }^{11}$. Meningkatnya kadar MDA pada kelompok yang dipapar cahaya LED putih di malam hari disebabkan karena tingkat kecerahan atau perubahan lingkungan cahaya yang tinggi akan bertindak sebagai pemicu stress bagi manusia, terutama bila tidak disengaja dan terlebih jika cahayanya biru dan memiliki suhu warna yang lebih dingin $(\geq 6500 \mathrm{~K}){ }^{1}$ sehingga ketika terpapar sumber stressor seperti paparan cahaya LED di malam hari atau paparan cahaya berlebih (durasi dan intensitas) maka fotooksidan dan radikal reaktif yang dihasilkan akan meningkatkan kadar peroksidasi lipid.

Selain menjadi sumber stressor, lampu LED putih yang mengandung cahaya biru juga sangat sensitif dalam mengganggu ritme biologis dan menekan sintesis melatonin ${ }^{12}$. Semakin besar intensitas cahaya yang diberikan (cahaya lampu yang semakin putih atau cahaya yang lebih dingin) maka semakin besar proporsi gelombang cahaya biru dalam spektrum ${ }^{1}$. Penelitian yang dilakukan oleh Sroykham dan Wongsawat (2013) telah membuktikan bahwa cahaya LED biru secara signifikan menekan produksi melatonin sebesar $91 \%$ pada orang dewasa. Sintesis melatonin yang terganggu akan menurunkan pertahanan antioksidan endogen terhadap radikal bebas atau Reactive Oxygen Species $(\mathrm{ROS})^{13}$. Sintesis melatonin akan menurun seiring paparan cahaya yang diberikan di malam hari. Melatonin bersifat sebagai antioksidan yang kuat, sehingga bila jaringan otak terpapar cahaya di malam hari maka jaringan tersebut menjadi lebih sensitif terhadap peroksidasi lipid. Dalam penelitian ini terlihat bahwa seiring dengan paparan cahaya LED putih di malam hari semakin lama paparan 
yang diberikan maka semakin meningkat pula peroksidasi lipid di jaringan otak.

Terganggunya pertahanan antioksidan endogen karena ditekannya melatonin membuat produksi radikal bebas menjadi tidak simbang dengan antioksidan yang menyebabkan terjadinya stress oksidatif, terutama di otak karena jaringan otak sangat rentan terhadap kerusakan oksidatif. Konsumsi oksigen jaringan otak yang tinggi yang dapat menghasilkan radikal bebas dalam jumlah yang tinggi ${ }^{9}$, adanya paparan cahaya LED putih di malam hari akan membuat otak semakin banyak menghasilkan radikal bebas yang ditandai dengan kadar malondialdehid (MDA) yang tinggi. Tingginya kadar MDA membuat sel-sel menjadi rentan terhadap kerusakan, karena alasan ini dilakukan juga pemeriksaan mikroskopis daerah CA1 dan CA3 hipokampus. Hipokampus adalah bagian otak yang menjadi target dari hormon stress yang memiliki konsentrasi tinggi akan hormon kortikosteroid.

Meningkatnya sel rusak pada daerah CA3 dan CA1 hipokampus pada kelompok yang dipapar cahaya LED putih di malam hari disebabkan karena hipokampus terutama bagian cornu ammonis rentan dari pengaruh stress. Stress oksidatif membuat kadar peroksidasi lipid meningkat dan menyebabkan akumulasi deposit-deposit metabolit yang sifatnya neurotoksik yang mengganggu aktivitas enzim $\mathrm{Ca}^{2+}$ ATPase yang berperan dalam proses regulasi konsentrasi $\mathrm{Ca}^{2+}$ intraseluler. Gangguan ini dapat memicu terjadinya degenerasi neuron pada hipokampus yang ditandai dengan perubahan pada struktur sel atau jaringan. Munculnya berbagai gangguan ini bisa merusak protein dan lipid pada membran sel, modifikasi membran serta fungsi seluler yang pada akhirnya menyebabkan kematian sel neuron cornu ammonis di hipokampus ${ }^{1,4}, 9$.

Cahaya merupakan salah satu sumber stressor apabila waktu, intensitas, durasi dan panjang gelombangnya sesuai. Pada keadaan stress, hormon glukokortikoid akan disekresikan. Stress yang timbul akan mempengaruhi sumbu hipotalamus-hipofisisadrenal (HHA) yang menghasilkan glukortikoid. Hormon glukortikoid bekerja terutama di hipokampus karena hipokampus mengandung reseptor tertinggi untuk hormon ini. Glukortikoid yang dihasilkan dalam jumlah yang berlebih akan menyebabkan umpan balik negatif pada reseptor glukokortikoid sehingga aktivitas HHA akan terhambat ${ }^{15},{ }^{16}$. Diseksresikannya hormon ini sebagai sinyal neurotoksik bagi hipokampus dan bila disekresi dalam jumlah yang berlebihan maka akan menyebabkan kematian pada sel neuron ${ }^{15}$. Kondisi stress ini juga dapat dialami tikus putih golongan Wistar dikarenakan tikus ini merupakan model yang cocok untuk mempelajari efek stress akibat cahaya dimana efek toksik dari paparan cahaya di malam hari yang dialami oleh tikus meniru efek serupa pada manusia ${ }^{11}$.

Hipokampus rentan mengalami nekrosis karena kebutuhan metabolismenya yang tinggi. Kerusakan neuron pada hipokampus juga dipengaruhi oleh stress. Jika terjadi kerusakan, sel akan mengalami pembengkakan akibat pembengkakan struktur seluler di dalamnya seperti mitokondria. Pembengkakan ini yang kemudian dapat menyebabkan lisis pada sel yang selanjutnya akan menyebabkan nekrosis sel. Sel yang mengalami nekrosis berubah bentuk menjadi hiperkromatik dan mengecil.

Stress yang berkelanjutan akan mengganggu fungsi sel terutama pada sel-sel yang rentan terhadap stress oksidatif, seperti sel-sel neuron di lapisan cornu ammonis hipokampus ${ }^{14}$ yang membuat sel-sel ini menjadi rentan terhadap kerusakan. Kondisi ini yang kemudian berdampak pada morfologi dan menurunkan fungsi hipokampus sebagai pusat learning dan memory.

\section{KESIMPULAN DAN SARAN}

Paparan cahaya LED putih di malam hari dengan intensitas 1500 lux selama 15 hari dan 30 hari pada tikus tampaknya bersifat neurotoksik melalui peningkatan pembentukan ROS (Reactive Oxygen Species) di otak dan menyebabkan kerusakan sel terutama di daerah hipokampus. Peneliti menyarankan perlu adanya pengurangan intensitas dalam penggunaan lampu LED di malam hari.

\section{DAFTAR PUSTAKA}

1. Cho YM, Ryu SH, Lee BR, Kim KH, Lee E, Choi J. Effects of artificial light at night on human health: A literature review of observational and experimental studies applied to exposure assessment. Chronobiology International. 2015;32(9):1294-310.

2. Susilawati D, Rezkisari I. Pakar Ungkap Bahaya Lampu LED untuk Mata [Internet]. REPUBLIKA.CO.ID. 2019. Available from: 
https://republika.co.id/berita/gaya-hidup/infosehat/19/05/16/pr19he328-pakar-ungkapbahaya-lampu-led-untuk-mata

3. Moroba MM, Mabusela MS, Masyina F, Choma SSR. Increased body mass index and waist circumference exert opposite effects on body iron status: A systematic review. African Journal for Physical and Health Sciences (AJPHES). 2016;23(1).

4. Ashkenazi L, Haim A. Effect of Light at Night on oxidative stress markers in Golden spiny mice (Acomys russatus) liver. Comparative Biochemistry and Physiology - A Molecular and Integrative Physiology. 2013;165(3):3537.

5. Lunn RM, Blask DE, Coogan AN, Figueiro MG, Gorman MR, Hall JE, et al. Health consequences of electric lighting practices in the modern world: A report on the National Toxicology Program's workshop on shift work at night, artificial light at night, and circadian disruption. Science of the Total Environment. 2017;607-608:1073-84.

6. Widayati E. Oxidasi Biologi, Radikal Bebas, dan Antioxidant. Majalah Ilmiah Sultan Agung. 2012;50(128):26-32.

7. Susilawaty A, Ibrahim H, Ugi NT. Pemanfaatan Minyak Jelantah dengan Tambahan Ekstrak Daun Cengkeh ( Zyzygium aromaticum ) Sebagai Sabun Antiseptik dalam Menurukan Jumlah Kuman pada Telapak Tangan. Higiene. 2017;3(1):1521.

8. Winarsi H, Purwanto A, Dwiyanti H. Kandungan Protein dan Isoflavon pada Kedelai dan Kecambah Kedelai. Jurnal Biota. 2010;15(2):181-7.

9. Liu J, Wang A, Li L, Huang Y, Xue P, Hao A. Oxidative stress mediates hippocampal neuron death in rats after lithium-pilocarpineinduced status epilepticus. Seizure. 2010;19(3):165-72.

10. Nathiya VC, Vanisree AJ. Investigations on light -induced stress model and on the role of phyllanthus amarus in attenuation of stress related depression-with focus on $5 \mathrm{ht} 2 \mathrm{a}$ m-rna expression. Annals Of neurosciences. 2010;17(4):167-75.

11. Ahamed Basha A, Mathangi DC, Shyamala R. Effect of LED photobiomodulation on fluorescent light induced changes in cellular ATPases and Cytochrome c oxidase activity in Wistar rat. Lasers in Medical Science. 2016;31(9):1803-9.

12. Dominoni DM, Borniger JC, Nelson RJ. Light at night, clocks and health: From humans to wild organisms. Biology Letters. 2016;12(2):2-5.

13. Sroykham W, Wongsawat Y. Effects of LEDbacklit computer screen and emotional selfregulation on human melatonin production. Proceedings of the Annual International Conference of the IEEE Engineering in Medicine and Biology Society, EMBS. 2013;(July):1704-7.

14. Saputro JH, Sukmadi T. Analisa Penggunaan Lampu Led Pada Penerangan Dalam Rumah. Transmisi. 2013;15(1):19-27.

15. Arjadi F, Soejono SK, Maurits LS, Pangestu M. Jumlah Sel Piramidal CA3 Hipokampus Tikus Putih Jantan pada Berbagai Model Stres Kerja Kronik Number of CA3 Pyramidal Cell in Male Albino Rat Hippocampus Exposed to Various Chronic Work Stress Models. Mkb. 2014;46(4):197-202.

16. Wiyono N, Aswin S. Hubungan antara tebal lamina pyramidalis CA1 hippocampus dengan memori kerja pada tikus (Rattus norvegicus) pascastres kronik. Jurnal Anatomi Indonesia. 2007;1(1):104-11. 